Удк 94 : 323.173(672.4+669)

\title{
ПРОБЛЕМА СЕПАРАТИЗМУ В СУБСАХАРСЬКІЙ АФРИЦІ 1960-Х рр. НА ПРИКЛАДІ КОНГО ТА НІГЕРІЇ
}

\section{Латенко Володимир Сергійович}

аспірант,

ДУ «Інститут всесвітньої історії НАН України»,

м. Київ, Україна

ORCID: 0000-0003-1407-453X

martell@i.ua
Надіслано:

10.02.2020

Рецензовано:

03.03.2020

Прийнято:

15.03.2020

Стаття присвячена питанню поширення сепаратизму в субсахарському регіоні Африки 1960-х рр. на прикладі двох країн - Демократичної Республіки Конго (далі - Конго) та Нігерії. Акцентовано увагу на причинах появи сепаратистських рухів, їх переростання у формат квазідержавних утворень та боротьбу центральних урядів за територіальну єдність.

У рамках запропонованої статті методологія дослідження заснована на методі порівняльного аналізу. Кожна з двох країн, взятих до розгляду, має свою специфіку, водночас, вдалося виділити спільні риси, на основі яких можна провести загальну характеристику відцентрових тенденцій у країнах Субсахарської Африки в означений період. Зокрема, це стосується нових незалежних держав, що постали на політичній карті африканського континенту на початку 1960-х рр.

Встановлено, що частіше сепаратистські рухи виникали у провінціях, які мали потужний економічний потенціал та запаси природних ресурсів. Це, в свою чергу, забезпечувало можливість окремого існування тривалий термін, навіть в умовах збройного протистояння 3 центральним урядом. Ключовим елементом ставала також наявність або відсутність зовнішнього чинника, політичного та/або військового, який безпосередньо визначав події або ж здійснював вирішальний вплив на них. Особливо характерний цей фактор у контексті біполярного протистояння між двома геополітичними центрами, очолюваними США та СРСР, що прагнули зміцнити свій вплив у кожній окремо взятій географічній точці світу. Поява кожної незалежної субсахарської країни, кожен новий прояв сепаратизму і воєнний конфлікт, мали не лише внутрішній вимір, але стосувалися більш глобального контексту протистояння в умовах холодної війни.

Ключові слова: сепаратизм; Конго; Катанга; Південне Касаї; Нігерія; Біафра. 
Latenko Volodymyr, Ph.D. Student, Institute of World History of the National Academy of Sciences of Ukraine, Kyiv, Ukraine

The Problem of separatism in Sub-Saharan Africa of the 1960's on the Example of Congo and Nigeria

The article deals with the issue of separatism in the sub-Saharan world of Africa in the 1960's, on the example of two countries - the Democratic Republic of the Congo (more - Congo) and Nigeria. Emphasis is placed on the emergence of separatist movements that move into the format of quasi-state and the struggle of central governments for territorial unity.

In the framework of the proposed article, the research methodology is mainly based on the method of comparative analysis. Each of the two countries considered has its own specific features, and at the same time, it has been possible to distinguish common features because of which a general characterization of centrifugal trends in Sub-Saharan Africa over a given period can be drawn. In particular, this concerns the new independent states that appeared on the political map of the African continent in the early 1960's.

It was found that more often separatist movements arose in provinces that had strong economic potential and reserves of natural resources. This, in turn, provided for the possibility of separate existence for a long period, even in the face of armed confrontation with the central government. A key element was also the presence or absence of an external factor, political and / or military, that directly determined events or had a decisive influence on them. This factor is especially characteristic in the context of bipolar confrontation between two geopolitical centres, led by the US and the USSR, which sought to strengthen their influence at every single geographical point in the world. The emergence of each independent sub-Saharan country, each new manifestation of separatism and military conflict, not only had an internal dimension, but also concerned a more global context of confrontation in the Cold War.

Key words: separatism; Congo; Katanga; South Kasai; Nigeria; Biafra.

Латенко Владимир Сергеевич, аспирант, ГУ «Институт всемирной истории НАН Украины», г. Киев, Украина

\section{Конго и Нигерии}

Проблема сепаратизма в Субсахарской Африке 1960-х гг. на примере

Статья посвящена вопросу распространения сепаратизма в субсахарском регионе Африки 1960-х гг. на примере двух стран - Демократической Республики Конго (далее - Конго) и Нигерии. Акцентировано внимание на причинах появления сепаратистских движений, их перерастании в формат квазигосударственных образований и борьбе центральных правительств за территориальную целостность. 
В рамках предлагаемой статьи методология исследования преимущественно основана на методе сравнительного анализа. Каждая из стран, принятых к рассмотрению, имеет свою специфику, одновременно удалось выделить общие черты, на основе которых можно провести общую характеристику центробежных тенденций в странах Субсахарской Африки в указанный период. В частности, это касается новых независимых государств, появившихся на политической карте африканского континента в начале 1960-х гг.

Установлено, что чаще сепаратистские движения возникали в провинциях, которые имели мощный экономический потенциал и запасы природных ресурсов. Это, в свою очередь, обеспечивало возможность отдельного существования длительный срок, даже в условиях вооруженного противостояния с центральным правительством. Ключевым элементом становилось также наличие или отсутствие внешнего фактора, политического и/или военного, непосредственно определяющего события или осуществляющего решающее влияние на них. Особенно характерен данный фактор в контексте биполярного противостояния между двумя геополитическими центрами, возглавляемыми США и СССР, стремящихся укрепить свое влияние в каждой отдельно взятой географической точке мира. Появление каждой независимой субсахарской страны, каждое новое проявление сепаратизма и военный конфликт имели не только внутреннее измерение, но касались более глобального контекста противостояния в условиях холодной войны.

Ключевые слова: сепаратизм; Конго; Катанга; Южное Касаи; Нигерия; Биафра.

\section{Вступ}

Завершення Другої світової війни стало поштовхом для процесів деколонізації, внаслідок чого на політичній карті світу виникли десятки нових незалежних держав. На африканському континенті, особливо в субсахарському регіоні, ці процеси відбувалися із певним запізненням. Більшість країн, розташованих південніше від пустелі Сахара, стали незалежними в 1960-х рр. Із 46 країн Африки, які ООН відносить до субсахарських, 32 країни отримали політичний суверенітет саме в 1960-х pp. Зокрема, 1960 р., який був проголошений $\mathrm{OOH}$ «Роком Африки» деколонізувалися 17 колишніх залежних територій європейських метрополій, в тому числі Конго та Нігерія, що розглядаються в рамках цієї статті.

Сепаратизм в новоутворених державах став досить звичним явищем, оскільки кордони базувалися на старому колоніальному поділі, який не завжди враховував етнічні, релігійні, географічні та ін. особливості мешканців цих 
територій. Нерідко цілі народи опинялися розділеними, ставши частиною різних країн. В основі таких кордонів була закладена свого роду «міна уповільненої дії». Там, де протиріччя між різними суспільними елементами ставали особливо гострими, виникали вогнища протистояння та конфлікту. Найбільш яскравою ілюстрацією подібних процесів у пер. пол. 1960-х рр. стала Конголезька криза (Grubbs, 2003, p. 25), яку супроводжували сепаратистські рухи в провінціях Катанга та Південне Касаї; а в др. пол. 1960-х рр. - війна за незалежність нігерійської провінції Біафра.

\section{Аналіз останніх досліджень і публікацій}

Інтересу до даної проблематики у вітчизняній історіографії прослідковується дуже мало, конкретних досліджень поки що не існує. Увагу привертають праці західних науковців, зокрема американських: присвячених тематиці Конголезької кризи (Ж.-Б. Гаджаянді, Дж. Медейрос, Л. Намікас та ін.) та Біафранської війни (Е. Анедозі, С. Коул, К. Осудібіа). У російській сучасній історіографії простежуються окремі наукові роботи, що теж стосуються конголезької тематики (С. Мазов).

\section{Виділення невирішених раніше частин загальної проблеми}

Попри існування окремих дослідницьких праць зарубіжних учених, що присвячені розгляду конголезького та нігерійського сепаратизму, увітчизняній науці ця проблема залишається поза увагою. Крім того, опубліковані роботи переважно мають практичний прикладний характер і не покликані окреслити узагальнені закономірності та тенденції явища сепаратизму під час поставання нових незалежних держав субсахарського регіону.

\section{Формулювання мети і завдань статті}

Метою дослідження $\epsilon$ виділення та узагальнення характерних особливостей явища сепаратизму у країнах Субсахарської Африки 1960-х рр. на прикладі Конго та Нігерії. Для досягнення поставленої дослідницької мети варто провести загальний огляд та порівняльний аналіз кожного конкретного сепаратистського руху, що мав місце в країнах, взятих для розгляду.

\section{Виклад основного матеріалу дослідження}

Керуючись хронологічним принципом, розпочати огляд сепаратистських рухів варто з конголезьких територій. Власне, Республіка Конго (Леопольдвіль), якій дали таку назву в перші роки незалежного існування, щоб відрізняти їі від іншого сусіднього Конго зі столицею у Браззавілі, - офіційно постала на політичній карті світу 30 червня 1960 р. (Stanard, 2006, р. 16). Після тривалих дискусій у рамках проведення тематичних конференцій, Королівство Бельгія надало право своїй колишній колоніальній території на самовизначення. Однак, конголезьке суспільство та політичний клас не були готовими брати на себе повноту влади та всю відповідальність за 
долю країни. Та і як такого політичного класу сформовано ще не було. За даними дослідника С. Мазова, на момент отримання незалежності, в Конго серед 12 млн. населення, лише 16 осіб на всю країну мали вищу освіту, хоча й за спеціальністю «політичні науки» (Mazov, 2015, p. 22).

Бельгія як колишня метрополія прагнула і надалі зберігати важелі впливу на ситуацію в Конго, передусім, економічного характеру. Особливо це стосувалося багатих гірничорудних провінцій на Сході країни, які традиційно протягом десятиліть були стабільним джерелом прибутків для бельгійського та в цілому західноєвропейського капіталу. Відчувши загрозу для своїх економічних та загалом національних інтересів, бельгійці почали підтримувати дії, спрямовані на дезорганізацію та фактичний розпад тієї державної структури, якій нещодавно самі ж надали незалежність.

Утім, погляди на ситуацію бельгійців у метрополії та тих, хто вже певним чином вкорівнився на конголезькій території, суттєво різнилися. У червні 1960 р., ще до офіційного проголошення незалежності Конго, коаліція катангських політиків партії «КОНАКАТ» та бельгійських переселенців здійснила спробу опублікувати власну декларацію про незалежність у Катанзі. Уряд Бельгії на цьому етапі відкинув ці плани, хоча й не перестав підтримувати катангський сепаратизм як явище.

11 липня 1960 р. в рамках однойменної провінції було проголошено утворення «Держави Катанга» на чолі з лідером сепаратистської партії правого спектру Моїзом Чомбе зі столицею в м. Елізабетвіль. Жодна країна світу не визнала незалежність Катанги, на офіційному рівні проголошуючи дотримання принципу територіальної цілісності єдиної Республіки Конго на чолі з центральним урядом Патріса Лумумби та президентом Жозефом Касавубу. Бельгія формально залишалася осторонь процесу, але фактично активно надавала підтримку сепаратистам. Так, відомо, що до катангської жандармерії як одного із двох підрозділів силових структур разом із поліцією були прикріплені кілька сотень бельгійських офіцерів-інструкторів, які виконували адміністративні та організаційні функції. Також поширення набуло явище найманців з числа білого населення. Крім того, Бельгія постачала сепаратистам зброю та надавала фінансову підтримку, що дозволило не лише проголосити про від'єднання, але й силою зброї відстоювати його. Ці події увійшли в історію під назвою Катангська війна (1960-1963) (Hajayandi, 2013, pp. 47-50).

Поряд із Катангою, в Конго виникло й інше, хоч і значно менше за розмірами і розмахом, джерело нестабільності та сепаратизму. 14 червня 1960 р., за два тижні до дати набуття незалежності єдиною конголезькою республікою, було оголошено про утворення «Федеративної держави Південне Касаї». На перших порах ніхто особливо не надав значення появі такої квазідержави, ні всередині Конго, ні за його межами. 
За формальними ознаками, Південне Касаї відділилося ще від Бельгійського Конго, яке перебувало в підпорядкуванні офіційному Брюсселю. Проте територіальні межі утвореної в подальшому Республіки Конго включали в собі і Південне Касаї як частину єдиної провінції Касаї. До початку Катангської війни, центральний уряд Конго не вбачав великої загрози в цьому сепаратистському русі, який досить легко можна було ліквідувати. Проте з появою Держави Катанга, яка за площею в 16 разів перевищувала Південне Касаї (496 тис. кв. км проти 30 тис. кв. км) та мала з ним спільну територіальну межу на північному заході, ситуація суттєво ускладнилася.

8 серпня 1960 р. було сформовано «Гірничорудну державу Південне Касаї» зі столицею в м. Бакванга. Оскільки попередня структура так і не набула ознак державності, цього разу вони були оформлені. Очолював це утворення «президент» Альбер Калонджі, який пізніше, у 1961 р., надав собі титул мулопве, що фактично означав королівську владу. Фактично Бельгія використовувала Південне Касаї як передній фланг у Катангській війні. Це пояснюється тим, що дана місцевість $є$ ближчою до столиці, ніж Катанга, тому перші збройні сутички відбулися саме тут. Територія самопроголошеного Південного Касаї також містила гірничорудні шахти, тому бельгійські гірничодобувні компанії та навіть окремі представники французького та південноафриканського капіталу, підтримували режим Калонджі задля збереження своїх статків та подальшого їх примноження.

У ситуації, що склалася, центральний конголезький уряд П. Лумумби шукав опори для відновлення цілісності країни (Hickner, 2011, pp. 174-177). У липні 1960 р. до ООН надійшло звернення від уряду Конго з проханням про допомогу у збереженні територіальної цілісності країни. Рада Безпеки ООН на своєму засідання 12 липня 1960 р. прийняла Резолюцію № 143, яка передбачала створення Миротворчої місії ООН в Конго (відома під абревіатурою ONUC). Мандат місії передбачав виведення залишків бельгійських військових, які ще перебували на теренах Конго, надання технічної допомоги задля забезпечення порядку в країні. Водночас, П. Лумумба покладав сподівання на миротворчу місію у питання боротьби проти сепаратизму у бунтівних провінціях. Проте на цьому етапі отримав відмову, оскільки ООН розглядала ці питання в якості внутрішньополітичних, які повинні вирішити між собою самі конголезці. Однак, по мірі загострення ситуації в Катанзі, вже в 1961 р. було змінено дію мандата місії ONUC, який тепер включав «збереження територіальної цілісності і політичної незалежності Конго, попередження виникнення громадянської війни та забезпечення виведення із Конго всього іноземного військового персоналу, напіввійськових формувань і консультантів, які не знаходяться у підпорядкуванні Командування Організації Об’єднаних Націй, а також усіх найманців». Така реорганізація завдань для миротворчого контингенту стала 
вирішальним фактором впливу на ситуацію в охопленій сепаратизмом Катанзі. За весь час дії місії (1960-1964) їі контингент налічував близько 20 тис. миротворців з понад 30 країн світу (Namikas, 2002, pp. 111-121).

Варто окремо зауважити, що всі означені події відбувалися на фоні глобального біполярного протистояння - холодної війни. Два геополітичні табори, очолювані США та СРСР намагалися скористатися плодами деколонізації, в тому числі в Африці, та перетворити ту чи іншу нову незалежну країну на свою сферу впливу. Республіка Конго (Леопольдвіль), розташована в самому центрі африканського континенту, представляла собою зручну мішень для такого впливу (Mazov, 2015, p. 41).

На перших порах поширення сепаратизму в Конго уряд П. Лумумби звернувся за допомогою до адміністрації президента США Д. Ейзенхауера (Medeiros, 2009, p. 151), але останній прагнув уникнути прямого залучення Сполучених Штатів до конфлікту, відповівши відмовою (Kresse, 2003, p. 541). Цей крок у США пізніше вважатимуть помилковим, він принесе їм немало клопоту у боротьбі проти комуністичної загрози, яку у Вашингтоні вбачатимуть в діях П. Лумумби. А він, у свою чергу, попросив допомоги у американського суперника - СРСР. I хоч в обмеженому вигляді, але така допомога надійшла (Mountz, 2014, p. 28). Про це знали і у Вашингтоні. Про що свідчить інформація, оприлюднена під час брифінгу Ради національної безпеки США 25 липня 1960 р. (National Security Council Briefing, 1960). Зокрема, повідомлялося, що до столиці Конго прибули радянські чиновники та військові радники, які здійснюють вплив на ініціативи уряду П. Лумумби та координують його діяльність, особливо щодо аспектів, дотичних до інтересів СРСР. Крім того, вживаються термінові заходи задля створення засобів прямого зв'язку між Москвою та Леопольдвілем. Також СРСР надав Конго 5 літаків «Іл-18». Стурбованість Вашингтону діями і впливом СРСР в Конго підтверджують й інші матеріали, оприлюднені на брифінгах Ради національної безпеки США 15 вересня 1960 р. (National Security Council Briefing, 1960), 20 грудня 1960 р. (National Security Council Briefing, 1960), також документ, підготований посольством Сполучених Штатів у Конго (Paper Prepared in the Embassy in the Congo, undated) та ін. (Memorandum..., 1961).

У США існували значні побоювання щодо можливості повторення кубинського сценарію, але вже на теренах Конго. Саме тому після усвідомлення небезпеки проникнення СРСР і залучення його як активної сторони впливу на вирішення протистояння в Катанзі та на хід Конголезької кризи загалом, у Вашингтоні було вжито дій задля усунення загрози перетворення Конго на радянського сателіта. Ці дії носили як формальний характер через офіційні канали та посольство, так і неформальний - через таємні дії американських 
спецслужб. Крім того, США мали значний вплив на миротворчу місію в Конго, її завдання та активність (Souleyman, 2013, pp. 51-58).

У вересні-грудні 1961 р., в ході кривавого протистояння, урядові конголезькі війська повністю зайняли територію Південного Касаї, а 30 грудня 1961 р. було арештовано лідера сепаратистів регіону А. Калонджі. Це відкрило шлях до ліквідації квазідержавного утворення Гірничорудної держави Південне Касаї та входження його в тіло конголезької республіки.

Катангська війна тривала значно довше та зі змінним успіхом. Навіть підкорення Південного Касаї не гарантувало досягнення подібного результату в Катанзі. Проте вирішальний вплив на ситуацію мала зміна мандату місії ONUC в 1961 р. Ставши де-факто вже не миротворчою місією, а стороною конфлікту, яка сприяла одній з його сторін, в цьому випадку, центральному конголезькому уряду, за весь час бойових дій в Катанзі було проведено чотири воєнні кампанії. Перші три з них відбулися у серпні, вересні і грудні 1961 р. та не мали успіху. Лише через рік після цього, у грудні 1962 р. було проведено останню воєнну операцію, що тривала до січня 1963 р. та призвела до повалення сепаратистського режиму і відновлення конголезького суверенітету над провінцією Катанга.

3 огляду на вищезазначене, можна стверджувати, що зовнішній фактор мав вирішальний вплив на події в Конго та придушення хвилі сепаратизму зокрема. У західному світі зрозуміли, що вигідніше мати єдину конголезьку державу, ніж впливати на їі політику через маріонеткові режими в окремих частинах. А офіційним інструментом стала місія ONUC, яка у взаємодії із конголезькими військами, сприяла поступовому повернення під контроль центрального уряду бунтівних територій.

Через кілька років після завершення Конголезької кризи, виникло інше вогнище протистояння та сепаратизму у Субсахарській Африці, тепер на теренах Нігерії. Як і Республіка Конго, Нігерія отримала незалежність в «Рік Африки», 1 жовтня 1960 р. (Cole, 2005, pp. 12-13). На її території існувала своя «нігерійська Катанга» - провінція Біафра, так само розташована в південно-східній частині країни. Незалежна Нігерія постала на теренах, що були британською колонією. Територіальні кордони нової держави не враховували етнічні, релігійні, культурні та економічні особливості різних регіонів, що мусили складати тіло єдиної Нігерії. Для існування в умовах колоніального статусу такий стан був допустимим, але в умовах суверенного самовизначення надто різношерстим регіонам вжитися в одній державі виявилося дуже складно. Серед понад 250 народностей та етнічних груп Нігерії, особливо чисельними є чотири найбільші народності: хауса, йоруба, ігбо та фулані. Вони не лише компактно проживають у різних частинах країни, але й кардинально різняться за релігійною ознакою. Так, хауса та фулані 
проживають переважно у північних територіях та є, як правило, мусульманами; йоруба населяють південно-західну частину країни і сповідують в більшості християнство, а ігбо - південно-східну частину, дотримуючись традиційних культів та вірувань.

Перша половина 1960-х pp. позначена пошуком способу мирного співіснування між різними народностями в умовах політичного діалогу та принципу регіоналізації. Нігерія на початку свого незалежного існування здавалася країною, що успішно рухається на шляху демократичних перетворень та поєднує кращі європейські зразки владних структур, заснованих на основах коаліційності. Проте з часом кожна 3 ключових народностей прагнула отримати контрольний пакет в управлінні країною та визначенні її курсу. Базові протиріччя лише наростали, а готовність до діалогу ставала все меншою.

Після серії локальних конфліктів у 1966 р. і невдалих спроб кожної зі сторін домогтися переваги над іншою та закріпитися на території супротивника, густонаселена жителями ігбо провінція Біафра вирішила відокремитися від решти Нігерії, проголосивши свою незалежність (Osudibia, 2010,pp. 26-28). Відповідний декрет було видано 27 травня 1967 р., що поклало офіційний відлік громадянської війни в Нігерії, відомої також під назвою «Війна за незалежність Біафри» (Anaedozie, 2009, pp. 1-5).

Ще однією спільною характеристикою, яка робить ситуацію в Біафрі подібною до подій в конголезькій Катанзі - наявність великих запасів природних ресурсів, в даному випадку, нафтових покладів. 3 одного боку, це створює підвалини для економічної незалежності регіону, з іншого - у випадку збройного протистояння дає змогу протриматися якнайдовше, маючи ресурс. На відміну від самопроголошеної, але ніким у світі невизнаної Катанги, Республіку Біафра, очолювану президентом Чуквуемека Одумегву Оджукву, визнали чотири держави Субсахарської Африки - Габон, Кот-д’Івуар, Танзанія, Замбія, а також Гаїті. Проте ООН відмовилася від визнання незалежності Біафри. Єдність Нігерії офіційно підтримали СРСР та Велика Британія. Ряд країн, зокрема європейських, у заявах своїх представників ставали на бік повстанців - Франція, Іспанія та Португалія, але на формальне визнання Біафри вони були не готові.

Як показала практика нігерійсько-біафранської війни, яким би потужним не був економічний ресурс, коли ведеться боротьба на виснаження і супротивник має перевагу у військовій силі і не бачить жодних перешкод на шляху до мети, рано чи пізно він досягає їі. Після серії невдалих кампаній та перемінного успіху, наприкінці грудня 1969 p. розпочався широкомасштабний наступ урядових нігерійських військ під командуванням майбутнього президента Олусегуна Обасанджо. Загальна чисельність військ, 
що оточили Біафру, переважала 180 тис., було використано сили важкої артилерії, авіації та бронемашин. Війська Біафри налічували близько 70 тис. воїнів. Нігерійський уряд використовував не лише суто військові сили, але і чинник виснаження противника, зокрема, голодом. Ще 30 червня 1969 р. уряд Нігерії офіційно заборонив Міжнародному комітету Червоного Хреста надавати будь-яку гуманітарну допомогу, в т. ч. і продовольство, представникам бунтівної провінції. За час війни, переважно від голоду, померло 2 млн. жителів Біафри. Нігерійський уряд не зупинився ні перед чим і 13 січня 1970 р. прийняв капітуляцію повстанців.

\section{Висновки}

Таким чином, для появи та розгортання явища сепаратизму на теренах Субсахарської Африки 1960-х рр. необхідною умовою є присутність значних обсягів природних ресурсів, які дозволяють претендувати на вихід за межі економічної незалежності до незалежності політичної. Наявність або відсутність зовнішнього фактора підтримки сторони повстанців або центрального уряду і баланс сил, що виникає внаслідок цього, визначає результат протистояння, яке, як правило, має характер збройної боротьби.

У першому випадку, що розглядався, - сепаратистські квазідержавні утворення «Держава Катанга» та «Гірничорудна держава Південне Касаї»доля їхнього існування була визначена втручанням зовнішнього чинника, зокрема, Миротворчої місії ОOH в Конго (ONUC), яка ставши на бік центрального конголезького уряду фактично вирішила результат даного конфлікту. Крім того, ситуація в Республіці Конго опинилася на вістрі біполярного протистояння між США та СРСР в рамках Холодної війни, яка досягла африканського континенту. Хоча, дивним чином, але обидва цих геополітичних центри, навіть перебуваючи у протистоянні між собою та переслідуючи різні інтереси в Конго, тим не менш, сприяли зміцненню позицій центрального уряду та відновлення ним територіальної цілісності країни. Що ж до громадянської війни за незалежність Біафри, результати цього конфлікту показали, що навіть за наявності значного економічного ресурсу, але за відсутності зовнішньої підтримки, в умовах ізоляції, відновлення територіальної цілісності єдиної держави стає лише питанням часу.

\section{References:}

1. Anaedozie, E. (2009). Influence of public opinion on the United States foreign policy in Nigeria during the Nigeria-Biafra War, 1967-1970. D.Ed. Morgan State University, Baltimore.

2. Cole, S. (2005). Nigerian War - American politics: The evolution of U.S. foreign policy concerning of the Nigerian Civil War. D.Ed. University of Maryland, College Park. 
3. Grubbs, L. (2003). 'Literally a Continent to Win': The United States. Development, and the Cold War in Africa, 1961-1963. D.Ed. University of South Carolina, Columbia.

4. Hajayandi, J.-B. (2013). The Bright Side of the Coin: American Assistance Amid Contentious Involvement in the Congo from 1960 to 1965. D.Ed. Stony Brook University, Stony Brook.

5. Hickner, J. (2011). History will one day have its say': Patrice Lumumba and the black freedom movement. D.Ed. Purdue University, West Lafayette.

6. Kresse, K. (2003). Containing Nationalism and Communism on the "Dark Continent": Eisenhower's Policy Toward Africa, 1953-1961. D.Ed. The University at Albany, State University of New York, New York.

7. Mazov, S. (2015). Kholodnaya voyna v "serdtce Afriki". SSSR i congolezskiy krizis, 1960-1964 [Cold war in the "heart of Africa." USSR and Congolese crisis, 19601964]. Moscow: Russian Foundation for the Promotion of Education and Science.

8. Medeiros, J. (2009). The challenge of addressing the Congo as nation-state: American approaches to Sub-Saharan Africa policy, 1957-1961. D.Ed. Saint Louis University, St. Louis.

9. Memorandum From the Chief of the Africa Division, Directorate of Plans, Central Intelligence Agency (Tweedy) to the Deputy Director of Plans, Central Intelligence Agency (Bissell) (March 29, 1961). FRUS, Volume XXIII, Congo, 19601968. Doc. №79. Washington.

10. Mountz, W. (2014). Americanizing africanization: the Congo Crisis, 1960-1967. D.Ed. The University of Missouri-Columbia, Columbia.

11. Namikas, L. (2002). Battleground Africa: The Cold War and the Congo Crisis, 1960-1965. D.Ed. University of Southern California, Los Angeles.

12. National Security Council Briefing (July 25, 1960). FRUS, Volume XXIII, Congo, 1960-1968. Doc. №7. Washington.

13. National Security Council Briefing (September 15, 1960). FRUS, Volume XXIII, Congo, 1960-1968. Doc. №21. Washington.

14. National Security Council Briefing (December 20, 1960). FRUS, Volume XXIII, Congo, 1960-1968. Doc. №51. Washington.

15. Osudibia, K. (2010). Ethnic Conflicts and Political Instability in Nigeria. D.Ed. University of Colorado, Denver.

16. Paper Prepared in the Embassy in the Congo (undated). FRUS, Volume XXIII, Congo, 1960-1968. Doc. №67. Leopoldville.

17. Souleyman, S. (2013). Cold War battleground in Africa: American foreign policy and the Congo Crisis, January 1959 - January 1961. D.Ed. University of Arkansas, Fayetteville. 
18. Stanard, M. (2006). Selling the tenth province: Belgian colonial propaganda 1908-1960. D.Ed. Indiana University, Bloomington.

(C) Латенко В. С., 2020 